\title{
Perceptions of Teachers, Principals And School Supervisors on Students' Skills Using ICT in Learning in the Senior High School
}

\author{
Desi Rahmatina ${ }^{1^{*}}$, and Norasykin Mohd Zaid ${ }^{2}$ \\ ${ }^{1}$ Department of Mathematics Educational, Faculty of Teacher Training and Education, Raja Ali Haji Maritime University, Indonesia \\ ${ }^{2}$ Department of Educational Sciences, Mathematics and Creative Multimedia, Faculty of education, Universiti Teknologi Malaysia \\ *Corresponding author: desirahmatina@umrah.ac.id
}

\section{ARTICLE HISTORY}

Received : April 9, 2018

Revised : February 12, 2019

Accepted : March15, 2019

\section{KEYWORDS}

Perception;

Computer;

Mobile Phone;

Internet;

Learning;

\begin{abstract}
This study examined on status of school (public and private school) differences for the perceptions of participats (teachers, principals and school supervisors ) in eleven senior high school on the students skills of Information and Communication Technology (ICT) in Tanjungpinang city, Kepulauan Riau Province, Indonesia. Data was taken by the use of online survey in 2016 who conducted by the Directorate General of Primary and Secondary Education of the Republic of Indonesia. We accumulate data from 310 respondents, they are 11 principals, 9 supervisors and 290 teachers on the eleven senior high school of Tanjungpinang district, Kepulauan Riau Province, Indonesia. Data analysis was done using quantitative analysis, the first using descriptive statistics mainly percentages perceptions of the principal, supervisor and teachers toward skill's students using ICT in learning, the second to inferential statistical analysis of non parametric statistics Mann Whitney to test alternative hypothesis that there are significant difference skill's students among public school and private school. SPSS software was used to analyze data. The results of the study shown that no different significantly on the students skill on use of computer in learning between public and private school (sig $=0.057$ ), and there are different significantly on the students skill on use of mobile phone in learning between public and private school $(\mathrm{sig}=0.001)$ and last result showed that there are different significantly on the students skill on use of internet in learning between public and private school (sig $=0.026$ ).
\end{abstract}

\section{INTRODUCTION}

Information and Communication Technology(ICT) is important role in education to support teaching and learning from the use of computer, mobile phone and internet.In this era of ICT, students have an easy to access of information in learning, but the determining factor for use ICT is facilities to support ICT in the school [1] and cost that may limit ICT integration in schools, and also dependent on the preparation of teachers [2]. Several research studies show that perception teacher towards students skill use of ICT [3],[4],[5].

In the act of the Republic of Indonesia Number 20, year 2003 states that the level of formal education in Indonesia is divided into three levels, namely basic education( 6 years of elementary school and 3 years of junior high school), secondary education (3 years of senior high school) and higher education (diploma, bachelor, masters,specialized postgraduate programmes and doctorate programmes). In the secondary education takes the form of senior general secondary schools, that is, Sekolah Menengah Atas (SMA) as well as Madrasah Aliyah(MA), and senior vocational secondary schools, that is, Sekolah Menengah Kejuruan (SMK), as well as Madrasah Aliyah Kejuruan (MAK), or other schools of the same level [6].

Computers are used in schools as learning to acquire skills and computer knowledge, moreover, senior high school in Indonesia, the subjects of Information and Communication Technology include the mastery of computer skills, the working principles of various types of communication equipment and how to acquire, process and communicate information. [3] studies teachers' perceptions, competency and use of computers among 134 secondary school teachers in Puducherry, India. The study reported that Age,gender,training in computers teaching subject showed that there is no significant difference in the teachers' perception on use of computers.

As well as of computers, mobile phone can also be help students in meaningful and access the lesson easily[7] and use mobile phones, students easily to aceess the internet. According to [8], many students made occasional use of the appointment calenders built into mobile phones, based on the results of their research showed that students have constant 
access to the website through mobile phones. Mobile phone also benefits in the classroom, from a survey of 1,121 teachers [9] found that students use mobile phones in the classroom to access the internet. The internet also can be used for collaboration, communication and problem solving [10]. There are some researches being done studies to investigate the differences in use of ICT skills, such as [10] concluded that there are no significant gender differences in ICT competencies among the pre university students, [11] examined that the attractiveness of different types of ICT applications in education for gender and ethnic differences in pupils' use ICT in primary and secondary education. Now, this study different from previous studies that in this study to examine there are different ICT skills among students between public and national school.

This study supports some literatures on the perceptions of teachers in use of the ICT [12],[2],[1],[13]. They were studied about computers \& Education Teacher perceptions on the use of digital gamified learning, Teachers' perceptions about ICT for teaching, professional development, The Use and Perception of ICT among Educators and about Primary Teachers ' Perceptions on ICT Integration for Enhancing Teaching and Learning through the Implementation of one Laptop. In addition from this study, we were examined not only the teacher's perceptions but also perceptions of principals and school supervisors on students' skills using ICT in learning. senior high school in Tanjungpinang city and then to analyze hypothesis there are difference significantly on the students skill on use of ICT among national school and private school using non parametric statistics Mann Whitney. Students skill on use of ICT contain three components, namely, skills of use of computer, use of mobile phone and use of internet.

The study has the benefit to give information to goverment about students skill in learning using of ICT, the survey has done by the Directorate General of Primary and Secondary Education of the Republic of Indonesia in 2016, however, we will continue the survey to test there are difference students skill use of ICT in learning among national school and private school. The study about using of ICT in learning in Indonesia have studied by [14], she was studied using wingeom software to improve critical thinking in geometri learning.

\section{RESEARCH DESIGN}

\subsection{Sample}

The participants of this study were 11 senior high school, there are 6 national school and 5 private schools and 11 principal, 9 supervisor and 290 teachers in Tanjungpinang districs of the Kepulauan Riau province.

\section{PURPOSE OF THE STUDY}

Purpose of the study is present the perceptions of teachers,principals and school supervisors in eleven senior high school on the skills use of ICT in learning in the

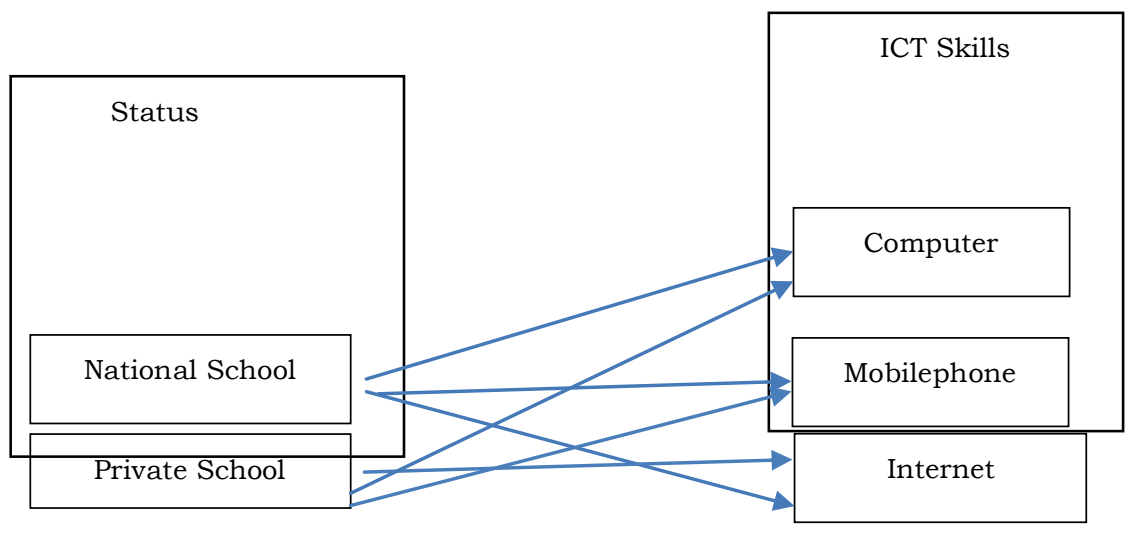

Fig 1. Theoretical Framework

Table 1. Percentage skill's of use ICT in Learning

\begin{tabular}{lcccc}
\hline \multicolumn{1}{c}{ USE ICT } & Unable & Less able & Able & Very Capable \\
\hline Computer & $0,0 \%$ & $5,5 \%$ & $58,1 \%$ & $36,4 \%$ \\
\hline Smart phone & $0,0 \%$ & $0,6 \%$ & $45,8 \%$ & $53,6 \%$ \\
\hline internet & $0,0 \%$ & $1,9 \%$ & $53,9 \%$ & $44,2 \%$ \\
\hline
\end{tabular}

There are 5,5\% of students less able and 95\% able and very capable to use computer and $0,6 \%$ of students less able and $99,4 \%$ of students able and very capable to use mobile phone in learning and then there are 1,9\% of students less able and $98,1 \%$ able and very capable to use internet in learning, for this information about percentages of perception of the use ICT in learning can be summarized that students of the senior high school in Tanjungpinang city skill's of use ICT in learning. 
Table 2. Profiles of the participating of the study

\begin{tabular}{|c|c|c|c|c|c|}
\hline Name of School & $\begin{array}{l}\text { Number of } \\
\text { Teachers }\end{array}$ & $\begin{array}{c}\text { Number of } \\
\text { school } \\
\text { principal }\end{array}$ & $\begin{array}{c}\text { Number of school } \\
\text { supervisor }\end{array}$ & Total & Percent \\
\hline SMAN 1 TANJUNG PINANG & 64 & 1 & 1 & 66 & $21,3 \%$ \\
\hline SMAN 2 TANJUNG PINANG & 49 & 1 & 1 & 51 & $16,5 \%$ \\
\hline SMAN 3 TANJUNG PINANG & 32 & 1 & 1 & 34 & $11,0 \%$ \\
\hline SMAN 4 TANJUNG PINANG & 46 & 1 & 1 & 48 & $15,5 \%$ \\
\hline SMAN 5 TANJUNG PINANG & 29 & 1 & 0 & 30 & $9,7 \%$ \\
\hline SMAN 6 TANJUNG PINANG & 28 & 1 & 1 & 30 & $9,7 \%$ \\
\hline SMAS KATOLIK SANTA MARIA & 11 & 1 & 1 & 13 & $4,2 \%$ \\
\hline $\begin{array}{l}\text { SMAS MUHAMMADIYAH } \\
\text { TANJUNGPINANG }\end{array}$ & 8 & 1 & 1 & 10 & $3,2 \%$ \\
\hline SMAS MUHAMMADYAH & 9 & 1 & 1 & 11 & $3,5 \%$ \\
\hline SMAS PELITA NUSANTARA & 6 & 1 & 1 & 8 & $2,6 \%$ \\
\hline SMAS PGRI TPI TIMUR & 8 & 1 & 0 & 9 & $2,9 \%$ \\
\hline
\end{tabular}

\subsection{Data Analyses and Results}

Data analyses were done using quantitative analysis such as descriptive analyze about percentages students skill on the using of ICT and then analyze hypothesis test which were used with the SPSS v.23 programme. Responents was choiced of the one answer for the likert scaled questions using 4-point scales for students skill on the ICT (computer, smartphone and internet) in learning, it was $1=$ strongly no experts ; $4=$ Srongly expert). All respondents have filled the questionnaire with a link to a website that provided by the Directorate General of Primary and Secondary Education of the Republic of Indonesia in 2016, we have got the secondary data and then we have analyzed descriptive and inferential statistics. Data analyze which were used is non parametric statistics Mann whitney to test whether there are significant difference students skill on use of ICT in learning among national school and private school. Three hypotheses were tested of this study, firstly, there are there are significant difference student skill on use of computer in learning among national school and private school, secondly, there are significant difference student skill on use of smart phone in learning among national school and private school and thirdly, there are significant difference student skill on use of internet in learning among national school and private school.

Table 3. ICT Rankings

\begin{tabular}{llrrr}
\hline \multicolumn{1}{c}{ Skills of ICT } & \multicolumn{1}{c}{ Status of school } & N & Mean Rank & \multicolumn{1}{c}{ Sum of Ranks } \\
\hline \multirow{2}{*}{ Computer } & National School & 259 & 151,76 & 39305,00 \\
\cline { 2 - 5 } & Private School & 51 & 174,51 & \\
\cline { 2 - 5 } & Total & 310 & 149,05 & 1890,00 \\
\hline \multirow{2}{*}{ Smart phone } & National School & 259 & 38604,50 \\
\cline { 2 - 5 } & Private School & 51 & 151,13 & \\
\cline { 2 - 5 } & Total & National School & 259 & 177,72 \\
\hline
\end{tabular}

In table 3 shown that mean rank in groups of skills use of computer,mean rank of the national school is 151.76 less than mean rank of the private school 174.51. And mean rank of skills use of smart phone and internet in learning also national school less than the private schools. Next, we were analyzed there was a significant different of mean rank on the national school and private school by used Mann Whitnet test, the results of the Mann Whitney test are summarized in Table 4. 
Tabel 4. Mann Whitney Test Statisticsa

\begin{tabular}{lrrr}
\hline \multicolumn{1}{c}{ Statistics Test } & Expert use of computer & Expert use of handphone & Expert use of Internet \\
\hline Mann-Whitney U & 5635,000 & 4934,500 & 5471,500 \\
\hline Wilcoxon W & 39305,000 & 38604,500 & 39141,500 \\
\hline Z & $-1,906$ & $-3,295$ & $-2,225$ \\
\hline Asymp. Sig. (2-tailed) &, 057 &, 001 &, 026 \\
\hline
\end{tabular}

a. Grouping Variable: status of school

Based on the Mann Whitney analysis was found that

1. Mann Whitney value for the students skill on the use of computer is 5635 and the Wilcoxon value is 39305 , it was converted to $Z$ value is $-1,906$ with the $\operatorname{sig}(2$ tailed $)=$ 0,057 greather than 0,05 , so we can conclude that no significant status of school difference for students skill of use computers in learning.

2. Mann Whitney value for the students skill on the use of smart phone is 4934.5 and the Wilcoxon value is 38604.5 , it was converted to $Z$ value is -3.295 with the $\operatorname{sig}(2$ tailed $)=0,001$ less than 0,05 , so we can conclude that there was a significant status of school difference for students skill on the use of smart phone in learning.

3. Mann Whitney value for the students skill on the use of internet is 5471.5 and the Wilcoxon value is 39141.5 , it was converted to $Z$ value is -2.225 with the $\operatorname{sig}(2$ tailed $)=$ 0,026 less than 0,05 , so we can conclude that there was a significant status of school difference for students skill on the use of internet in learning.

\section{CONCLUSSION}

The research indicated that there are no significant status of school difference on students' skills using computer among national school and private school, however, it was found there was a significant difference on students' skills on the use of smart phone and internet based perception of teachers, principals and school supervisors in the Senior High School.

\section{REFERENCES}

[1]G. Mura and D. Diamantini, "The Use and Perception of ICT among Educators: the Italian Case," Procedia - Soc. Behav. Sci., vol. 141, pp. 1228-1233, 2014.

[2]C. Technology, "Teachers' perceptions about ICT for teaching, professional development, administration and personal use Alcuin Mwalongo Dar es Salaam University College of Education , Tanzania," vol. 7, no. 3, pp. 36-49, 2011.

[3]M. Padmavathi, "A Survey of Secondary School Teachers ' Perceptions, Competency and Use of Computers," vol. 2, no. 4, pp. 7-16, 2013.

[4]P. Basargekar and C. Singhavi, "Factors Affecting Teachers' Perceived Proficiency in Using ICT in the Classroom Prema Basargekar \& Chandan Singhavi K . J . Somaiya Institute of Management Studies and Research , India," vol. 5, no. 2, 2017.

[5]L. Naima, "Exploring the Status and Teachers' Perceptions of Technology Integration in EFL," vol. 8, no. 2, pp. 160-170, 2017.

[6]"Act of the Republic of Indonesia on National Education System 1," no. 20, pp. 1-58, 2003.
[7]P. Thornton and C. Houser, "Using mobile phones in English education in Japan," pp. 217-228, 2005.

[8]P. Thornton and C. Houser, "Using Mobile Phones in Education," 2004.

[9]B. W. O. Bannon and K. M. Thomas, "SC," Comput. Educ., 2015.

[10]T. S. Hew and L. Y. Leong, "An Empirical Analysis of Malaysian Pre-university Students â€TM ICT Competency Gender Differences," vol. 2, no. 1, pp. 15-29, 2011.

[11]M. Volman, "New technologies, new differences . Gender and ethnic differences in pupils ' use of ICT in primary and secondary education," vol. 45, pp. 35-55, 2005.

[12]A. Adukaite and I. Van Zyl, "Computers \& Education Teacher perceptions on the use of digital gami fi ed learning in tourism education: The case of South African secondary schools," vol. 111, pp. 172-190, 2017.

[13]T. Education, "Primary Teachers' Perceptions on ICT Integration for Enhancing Teaching and Learning through the Implementation of One Laptop Per Child Program in Primary Schools of Rwanda," vol. 8223, no. 11, pp. 7193-7204, 2017.

[14]D. Rahmatina, "Penggunaan Program Wingeom Pada Materi Bangun Ruang Sisi Lengkung Untuk Meningkatkan Kemampuan Berpikir Kritis Mahasiswa," 2016. 